\title{
Medicinal plants in cultures of Afro-descendant communities in Brazil,
}

\section{Europe and Africa}

\section{Maria Corette Pasa ${ }^{1 *}$ (D), Natalia Hanazaki ${ }^{2}$ (D), Olga Maria Duarte Silva ${ }^{3}$ (D) Adelaide Bela Agostinho 4 (D), Sofia Zank ${ }^{2}$ (1) and Maria Inês Pires Neves Esteves ${ }^{3}$ (i)}

Received: May 14, 2019

Accepted: May 20, 2019

\section{ABSTRACT}

Ethnomedicine focuses on empirical and traditional knowledge of healing practices of different human groups, including the use of plants as medicine. We aimed to determine whether there is consensus regarding the use of plants in traditional medicine of Afro-descendant communities in Brazil, Europe and Africa. Data were obtained through interviews, walks-in-the-woods, participant observations and bibliographic searches. We analyzed similarities among data sets to determine whether there is convergence in the use of traditional medicinal plants among these communities considering that they share influence from African culture and a common spoken language (Portuguese). Similarities among communities were assessed through cluster analysis using presence or absence data for the variables. We recorded 405 medicinal plants, most of which were spontaneously occurring, although some were cultivated. The most represented botanical families were Asteraceae and Lamiaceae. Similarity in medicinal plants among communities was found to be tenuous due to the biogeographical and spatial characteristics of the biomes, and to historical and cultural peculiarities of each locality, resulting in different sets of medicinal plants. This study contributes to understanding the role of the historical legacies of the African diaspora and of European (Portuguese) expansion in the adaptation and maintenance of new elements in local floras.

Keywords: African diaspora, cultural exchange, ethnobotany, medicinal plants, traditional medicine

\section{Introduction}

To Mr. Antônio Benedito da Silva, known as Antônio Mulato (in memoriam), for the traditional legacy left from the 113 years of his life in Quilombo Mata Cavalo, Mato Grosso, Brazil.

Ethnomedicine, also known as the study of traditional medicine practiced by ethnic groups, employs interdisciplinary methods of ethnobotany and anthropology to focus on traditional knowledge that is transmitted orally between generations (WHO 2002). We define traditional medicine as not only a practice, but also the knowledge and beliefs that incorporate herbal, animal or mineral remedies, spiritual therapies, manual techniques and exercises singly or in combination to maintain well-being and to treat, diagnose, or prevent diseases. The use of medicinal plants is central to several ethnic groups. According to the World Health Organization, "a medicinal plant is a plant that contains in one or more of its organs substances that can be used for therapeutic or preventive

1 Departamento de Botânica e Ecologia, Universidade Federal de Mato Grosso, 78060-900, Cuiabá, MT, Brazil

2 Laboratório de Ecologia Humana e Etnobotânica, Departamento de Ecologia e Zoologia, Universidade Federal de Santa Catarina, 88040-900,

Florianópolis, SC, Brazil

3 Laboratório de Farmacognosia, Faculdade de Farmácia, Universidade de Lisboa, 1649-003, Lisboa, Portugal

4 Centro de Investigação e Desenvolvimento em Etnobotânica, Ensino Superior e Técnico Profissional, Ministério da Ciência e Tecnologia de

Moçambique, 1116, Namaacha, Mozambique

* Corresponding author: pasaufmt@gmail.com 


\section{Medicinal plants in cultures of afro-descendant communities in Brazil, Europe and Africa}

purposes or that can be used in the pharmaceutical industry after being chemically modified" (WHO 2007).

The word Afro-descendant comprises two words - "Afro", which refers to Africans, and "descendant", which comes from generation - and thus means "the descendancy of Africans" (Munanga 2004). According to Salas et al. (2004), more than 13 million people from Africa have been traded as slaves between the Old and New Worlds, mainly to the Americas, during four centuries of history. Today, descendants of this forced movement inhabit several parts of Brazil, as well as Europe and other continents outside Africa. For example, Quilombos (sometimes referred to as maroon settlements) are traditional groups of Afro-Brazilian descendants who identify themselves as such with their own history, including African ancestry and an identity related to historical resistance to oppression (Ávila et al. 2015). Another example is the Afro-Portuguese, who are Portuguese citizens of African ancestry. Yet another example is in Africa, such as in the countries of Guinea-Bissau and Mozambique, where sub-Saharan populations composed of blacks and native societies are also referred to as Afrodescendants (M'Bokolo 2007). These traditional peoples share important characteristics, such as living in rural areas near forests where dependence on nature, its cycles, and its products are fundamental to the organization, production and social reproduction of their cultural ways.

Some of these Afro-descendant societies depend on the local environment as a primary source of resources, especially plants for traditional medicine, and thus express ethnobotanical knowledge about the use of natural resources in their daily lives (Silva et al. 2006). We hypothesized that, in addition to intracultural characteristics of each region and historical and current socio-economic particularities, part of the ethnobotanical knowledge about medicinal plants held by these Afro-descendant communities is related to shared ancestry. Ethnobotanical studies with a focus on plants used in folk medicine can also evaluate the diffusion and erosion of cultures between the Old and New Worlds, which share historical and ethnic characteristics (Fonseca \& Balick 2018). Thus, this study aimed to determine whether there is a consensus regarding the use of plants in traditional medicine among Afro-descendant communities in Brazil and countries in Europe and Africa that currently share Portuguese as a common spoken language. We also discuss relationships among the different cultural and environmental frameworks of each study area and the clusters of plants used as medicine. The null hypothesis in this study is that there is no shared knowledge about plants with medicinal properties among these groups.

\section{Materials and methods}

\section{Study site}

We compiled data collected from four countries where Afro-descendants are Portuguese speakers: Brazil (Pasa et al. 2015; Zank et al. 2016), Portugal (Esteves \& Silva 2015), Guinea Bissau (Diniz et al. 2000) and Mozambique (Ribeiro et al. 2010). Five Brazilian communities were included in the study: Mata Cavalo de Cima and Mata Cavalo de Baixo are located near $15^{\circ} 46^{\prime} 9^{\prime \prime} \mathrm{S}$ and $56^{\circ} 21^{\prime} 6^{\prime \prime} \mathrm{W}$ in the state of Mato Grosso, where they are inserted in the Cerrado biome in the meso-region known as Baixada Cuiabana (IBGE 2010); Aldeia ( $28^{\circ} 06^{\prime} 23^{\prime \prime S} 48^{\circ} 40^{\prime} 43^{\prime \prime} \mathrm{W}$ ); Morro do Fortunato

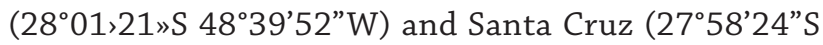
$48^{\circ} 41^{\prime} 16^{\prime \prime} \mathrm{W}$ ) are located in the state of Santa Catarina within the Atlantic Forest domain, where forest cover varies from dense rainforest to restinga (sand dune vegetation) (Ávila et al. 2015). In Europe, the Portuguese village Penha Garcia $\left(40^{\circ} 2^{\prime} 36.55^{\prime \prime} \mathrm{N} 6^{\circ} 58^{\prime} 40.93^{\prime \prime} \mathrm{W}\right)$ was included, which is in a region characterized by Mediterranean vegetation (Costa 1998). In Africa, data collection occurred in two areas of the Republic of Guinea Bissau, one in the Cantanhez "mata" region in the south and the other in Mangais do Cacheu National Park in the north $\left(12^{\circ} 23^{\prime} 36.5^{\prime \prime} \mathrm{N} 15^{\circ} 12^{\prime} 29.1^{\prime \prime} \mathrm{W}\right)$, both site of which possess open forest, dense forest, wooded forest and wooded savanna (Martins 1996). In Mozambique, data were collected in Canhane village, $\left(32^{\circ} 09^{\prime} 30^{\prime \prime} \mathrm{E}\right.$ $\left.24^{\circ} 4^{\prime} 30^{\prime \prime} \mathrm{S}\right)$, where the major habitat types are woodlands, savannas and grasslands (Gomes \& Barbosa 1995). Due to historical ties in the region of Mozambique in Africa, they speak a mix of Portuguese, Changana and creole languages.

\section{Ethnobotanical inventory}

We compiled secondary data originally obtained through the application of ethnobotanical techniques, such as semi-structured and open interviews (Tongco 2007; Minayo 1994; 2007), participant observations, guided tours and oral histories (Meihy 1996), with the addition of bibliographic information. Ethnobotanical data on plants used in traditional medicine was organized into five study regions: Quilombos in Mato Grosso (Pasa et al. 2015), and Quilombos in Santa Catarina (Zank et al. 2016), both in Brazil (South America); Penha Garcia Village in Portugal (Europe); and Guinea Bissau and Mozambique (both in Africa). Data were recorded as the presence or absence of a given species in the different study regions.

In Mato Grosso, the communities belonging to the Quilombo Boa Vida - Mata Cavalo complex are composed of 174 families. We interviewed 32 women (76\%) and 10 men (24\%). The economy is based on small subsistence farming and fishing, both for family consumption.

The communities of Santa Catarina have, on average, 30 to 35 residences and 90 to 130 inhabitants. They have traditional health practices, including the use of medicinal plants and the existence of healers. Catholicism is the main religion, followed by Evangelical Christianity. Data for these communities came from interviews performed by Zank et al. (2016).

Penha Garcia is a small village in the municipality of Idanha-a-Nova, Portugal. The community mainly consists 
of elderly people, mostly of European origin, with an AfroPortuguese minority who became established after the independence of the former Portuguese colonies in Africa (M'Bokolo 2007). A total of 40 women (80\%) and men $(20 \%)$ were interviewed. The age of the interviewees ranged from 45 to 90 years. The economy of the village is based on small-scale subsistence farming.

Data were collected in several localities in Guinea Bissau (Contuboel, Cantanhez, Bissau, Mangais do Cacheu), through interviews with 23 healers of different ethnic groups such as "balanta", "fula", "mandinga", "nalu" and "tanda" (Diniz et al. 2000). In the community of Canhane in Mozambique, a total of 11 informants were selected (six men and five women) as the best traditional knowledge holders. This selection was based on the size of the study site, homogeneity of the vegetation and indications provided by the community. The community has poor access to water resources, health services (the closest health center is located in the village of Massingir, which is seven kilometers away from Canhane), trading and communications, and has an obsolete energy system and an unsuccessful school system. The main activities are agriculture, followed by raising livestock and fishing, while handicraft production is a tertiary activity (Faria 2010; Ribeiro et al. 2010).

In Brazil, botanical identification followed Lorenzi \& Matos (2008), Lorenzi (2013), and the APG IV (APG IV 2016) classification system, while names followed the database of Flora of Brazil (floradobrasil.jbrj.gov.br) and the Missouri Botanical Garden (http://mobot.mobot.org/ W3T/Search/vast.html). Voucher specimens were deposited at FLOR (Federal University of Santa Catarina), EAFM (Federal Institute of Education, Science and Technology of Amazonas), and UFMT (Central Herbarium of the Federal University of Mato Grosso). In Portugal, botanical identification followed Nova Flora de Portugal (Franco 1984), and vouchers were deposited at LISC (Herbarium of the Tropical Research Institute, Lisbon). Vouchers from Guinea Bissau were also deposited at LISC. In Mozambique, vouchers were deposited at LMU (Herbarium of the Faculty of Sciences of the Eduardo Mondlane University, Maputo), while scientific names were based on Catarino (2002) and Ribeiro et al. (2010), and confirmed with the Database of African Tropical Plants and the International Plant Names Index, with additional information from LISC. Data on plant uses, types of uses, parts used, dosages and healthrelated categories, such as medicines, food, mystical, and religious were based on the literature (Agostinho 2002; Amorozo 2004; Albuquerque \& Hanazaki 2006, Silva et al. 2012; Zank et al. 2016; Pasa et al. 2017). Indications were grouped based on the classification of diseases proposed by International Classification of Diseases (ICD 10) of the World Health Organization (WHO 2014). Dendrograms produced by multivariate analysis using the Ward method and a Mahalanobis distance matrix revealed the formation of clusters with similar characteristics (Johnson \& Wichern
2007), considering the presence or absence (Hair et al. 2009) of each plant in each community. The use of presence/ absence data is justified because the original source of data for each locality varied, as did the sampling effort and those considered key informants (e.g. healers, local plant specialists, elderly). Sampling different environments is interesting because communities may express similar cultural characteristics, depending on historical circumstances, the botanical repertoire available where they live, and the botanical repertoire for introduced species. Statistical analysis may reveal homogeneity or heterogeneity among groups (Johnson \& Wichern 2007).

\section{Results}

\section{Sociocultural characteristics}

A total of 337 people were interviewed, of which $80 \%$ were female. Mostly women stayed in the residence taking care of the house and children at all of the localities. Men carried out activities as lumberjacks, foresters, or merchants in or around the community. The age of the interviewees ranged from 40 to 110 years. Knowledge about medicinal plants was predominantly held by older people. Young people sometimes remained in the community, especially in rural areas, because help was needed with domestic chores or cultivating subsistence crops. Few young people are able to attend school in the more remote localities, either due to lack of financial resources or because of the distance from the residence to the school. Most members of the community possess incomplete elementary education. The predominant religion is Catholic, followed by religions with African influence, such as traditional beliefs widely practiced on the continent.

The economic activities of the studied communities basically include cultivating subsistence crops, with families providing the labor force. Some of the communities had records of the sharing of rural work among neighbors, friends and relatives - a practice called "mutirão" in Brazilian communities. The activities of "mutirãos" do not imply economic costs for those who benefit from the services because they are shared on the basis of comradeship. In some cases economic activities are linked to urban areas, such as in the communities of Santa Catarina, Brazil, due to their proximity to nearby towns.

The main subsistence crops of families are obtained from a parcel in a farm landscape and include the plants Manihot esculenta, Musa sp., Carica papaya, Cucurbita sp., Punica sp., Zea mays, Ipomoea batatas, Saccharum sp., Senna occidentalis, Gossypium sp., and Citrus sp., among others. The plants used as medicine in therapeutic activities of traditional medicine are obtained from a variety of environments: (a) natural areas - forests with native species and for collective use; (b) anthropic areas - areas with wide human intervention characterized mainly by cultivated/domesticated species, such 


\section{Medicinal plants in cultures of afro-descendant communities in Brazil, Europe and Africa}

as backyards located near residences; (c) areas of regenerating vegetation - "capoeiras" in various stages of succession with the presence of exotic species and native species; and (d) areas of family domain - called "roças", where home-gardens are cultivated for small scale farming. Whatever the case, these spaces are located near homes in order to facilitate the acquisition of food and medicine, which are prepared mainly by women. Gardens and backyards are crucial resource sites for rural populations of these communities and represent a space for the cultivation of native species.

\section{Ethnobotanical knowledge}

A total of 405 native and exotic species were recorded as being used in traditional medicine. Eighty-six plant species from 78 genera and 45 botanical families were present at two or more localities and recorded with their ethnomedicinal uses by Quilombo communities. The most represented families were Asteraceae, Lamiaceae, Malvaceae and Rutaceae (Tab. 1).

In general, the plants used in the communities had multiple uses, with 1070 citations for the medicinal category (Tab. 2). The plants used in traditional medicine have a multitude of uses for treating health problems, with the number of citations varying according to the number of respondents and/or the size of the community. Due to the multiplicity of medicinal uses, the number of citations per species in each locality varied. In the African communities, each interviewee cited on average 10.2 uses per species, followed by the European community with 9.5 and the Brazilian communities with 5.2.

Among the plants present at two or more localities, the species with the highest frequencies of citations were Musa paradisiaca (75 citations); Carica papaya (64 citations); Citrus limon and Zingiber officiallis (62 citations each); Gossypium herbaceum, Ruta graveolens and Citrus x aurantium (60 citations each); Melissa officinalis (56 citations); Psidium guajava (55 citations); and Anacardium occidentale (54 citations) (Tab. 1). Some species do not appear in Table 1 because they were not present in two or three communities. Among these are Xylopia aethiopica, Voacanga africana, Saba senegalensis, Entada africana, and Afzelia africana, with high frequencies of citations for being present and native in Africa. The species Olea europaea, Pinus pinaster and Tilia europaea were cited with multiple medicinal uses and are present only in the European set of medicinal plants.

Plants used in religious rituals reveal their medicinal importance as protectors, such as Zingiber officialis, Ruta graveolens, Petiveria alliacea, Rosmarinus officinalis, Aloe vera, Mentha x villosa, Sanseviera trifasciata, Vernonia ferruginea, Justicia pectoralis, Echinodorus macrophyllus, Alternanthera brasiliana, Allium fistulosum, Dieffenbachia amoena, Porophyllum ruderale, Lactuca sativa, Matricaria chamomilla, Matricaria recutita, Mikania glomerata, Artemisia absinthium and Vernonia polyanthes. These plants are used topically in the form of a compress (either one plant or a combination of several species). Religious uses occur through blessings and prayers, individually or collectively, to treat "evil eye", sadness, weakness, envy and fallen ark.

We found that herbaceous plants are predominant among medicinal species in most of the Brazilian communities and in the European community. The part of the plant most used is the leaf (82\%), followed by the bark and fruits. Forms of preparation include tea ( $80 \%)$, followed by infusion, maceration and topical use (compress). The most commonly used part of the plant in the African communities was the root $(62 \%)$, followed by the leaf, which were employed by decoction, maceration and infusion.

Roots were the most used plant part for some species, such as $A$. africanus, $H$. africana, A. digitata, $X$. americana and $C$. abbreviata, with the forms of use being decoction, maceration and infusion, while leaves were the second most frequently used part. Roots, whole plants, bulbs and bark constitute $76 \%$ of the uses, while leaves, fruits and branches constitute $24 \%$ of the uses in the studied African communities (Ribeiro et al. 2010).

The species used medicinally were classified according to WHO (2014). Most use citations were for the circulatory system (54 spp.), followed by the digestive system (23 spp.), the genitourinary system (21 spp.) the respiratory system (13); for endocrine, nutritional and metabolic problems (12 spp. each); the nervous system (11 spp.); and personal or magical-religious protection (eight spp.). In general, the most frequently mentioned health treatments: general inflammation, stomach pain, hypertension, blood purification, bronchitis, worms, hemorrhoids, osteoporosis, diuresis, anemia, high cholesterol, tumors, cancer, dengue, malaria, sexually transmitted diseases, postpartum, heart problems, kidney stones, ulcers, purgatory, aphrodisiac, rheumatism, abortive diseases, malaise, bodily diseases, liver, coughing, vomiting, nervousness, genital lavage, circulation, constipation, wounds, eczema, bleeding, burns, constipation and bone pain. Other healing properties mentioned for the medicinal plants included reconditioning strength, weakness, depression, sadness, bad mood, affronts, evil eve and personal protection.

The localities have a coefficient of agglomeration of 0.87 , which is considered high since the coefficient ranges from 0 to 1 . Species of the Brazilian and African communities share $80 \%$ of their species (Fig. 1, Tab. 1). The community in Portugal is located in the second stratum of the amplitude and has the least similarity (17\%) in the use of medicinal plants among the studied communities (Fig. 1).

Lamiaceae and Asteraceae were the most representative families, with similar species for medicinal uses in the communities of Santa Catarina and Mato Grosso, Brazil, and Penha Garcia, Portugal, in the Atlantic Forest, Cerrado and Mediterranean Forest biomes, respectively (Tab. 2).

The agglomerative distribution of Lamiaceae grouped the species Rosmarinus officinalis, Plectranthus barbatus, Melissa 
Table 1. Similarity between the communities studied by presence or absence. Presence (P) and Absence (0); MT = Mato Grosso (Brazil); SC = Santa Catarina (Brazil); $\mathrm{PO}=$ Portugal (Europe); GB = Guine Bissau (Africa); MZ = Mozambique (Africa); Total = number of citations (absolute frequency).

\begin{tabular}{|c|c|c|c|c|c|c|c|c|c|c|c|c|c|}
\hline Species & MT & sc & PO & GB & MZ & Total & Species & MT & SC & PO & GB & MZ & Total \\
\hline Abelmoschus esculentus L. Moench & $\mathrm{P}$ & $\mathrm{P}$ & 0 & 0 & 0 & 18 & Jatropha gossypiifolia L. & $\mathrm{P}$ & $\mathrm{P}$ & 0 & $\mathrm{P}^{*}$ & 0 & 29 \\
\hline Adansonia digitata $\mathrm{L}$. & 0 & 0 & 0 & $\mathrm{P}^{*}$ & $\mathrm{P}^{*}$ & 56 & Justicia pectoralis Jacq. & $\mathrm{P}$ & $\mathrm{P}$ & 0 & 0 & 0 & 33 \\
\hline Allium fistulosum L. & $\mathrm{P}$ & $P$ & 0 & 0 & 0 & 43 & Lactuca sativa L. & $\mathrm{P}$ & $\mathrm{P}$ & $\mathrm{P}$ & 0 & 0 & 28 \\
\hline Aloe vera (L.) Burm f. & $\mathrm{P}$ & $P$ & 0 & 0 & 0 & 36 & Leonotis nepetifolia (L.) R. Br. & $\mathrm{P}$ & $P$ & 0 & 0 & 0 & 18 \\
\hline Alternanthera brasiliana (L.) Kuntze & $\mathrm{P}$ & $\mathrm{P}$ & 0 & 0 & 0 & 37 & Malva sylvestris L. & $\mathrm{P}$ & $\mathrm{P}$ & 0 & 0 & 0 & 35 \\
\hline Anacardium occidentale L. & $\mathrm{P}$ & 0 & 0 & $\mathrm{P}^{*}$ & 0 & 54 & Manihot esculenta Crantz & $\mathrm{P}$ & $\mathrm{P}$ & 0 & 0 & 0 & 48 \\
\hline Ananas comosus (L.) Merr. & $\mathrm{P}$ & $\mathrm{P}$ & 0 & 0 & 0 & 30 & Matricaria chamomilla L. & $\mathrm{P}$ & $\mathrm{P}$ & 0 & 0 & 0 & 36 \\
\hline Annona acutiflora Mart. & $\mathrm{P}$ & $\mathrm{P}$ & 0 & 0 & 0 & 30 & Matricaria recutita L. & $\mathrm{P}$ & $\mathrm{P}$ & 0 & 0 & 0 & 25 \\
\hline Artemisia absinthium L. & $\mathrm{P}$ & $\mathrm{P}$ & 0 & 0 & 0 & 28 & Maytenus aquifolium Mart. & $\mathrm{P}$ & $\mathrm{P}$ & 0 & 0 & 0 & 38 \\
\hline Asparagus africanus Lam. & 0 & 0 & 0 & $\mathrm{P}^{*}$ & $\mathrm{P}^{*}$ & 51 & Melissa officinalis L. & $\mathrm{P}$ & $\mathrm{P}$ & 0 & 0 & 0 & 56 \\
\hline Bauhinea forficata $\mathrm{L}$. & $\mathrm{P}$ & $\mathrm{P}$ & 0 & 0 & 0 & 37 & Mentha pulegium L. & $\mathrm{P}$ & $\mathrm{P}$ & 0 & 0 & 0 & 52 \\
\hline Beta vulgaris $\mathrm{L}$. & $\mathrm{P}$ & $\mathrm{P}$ & 0 & 0 & 0 & 03 & Menthax x villosa Huds. & $\mathrm{P}$ & $\mathrm{P}$ & $\mathrm{P}$ & 0 & 0 & 35 \\
\hline Brassica oleracea L. & $\mathrm{P}$ & $\mathrm{P}$ & 0 & 0 & 0 & 16 & Mikania glomerata Spreng. & $\mathrm{P}$ & $\mathrm{P}$ & 0 & 0 & 0 & 28 \\
\hline Bryophyllum pinnatum (Lam.) C & $\mathrm{P}$ & $\mathrm{P}$ & 0 & 0 & 0 & 12 & Musa parasidiaca L. & $\mathrm{P}$ & $P$ & 0 & $\mathrm{P}^{*}$ & 0 & 75 \\
\hline Cajanus cajan (L.) Huth & $\mathrm{P}$ & $\mathrm{P}$ & 0 & 0 & 0 & 18 & Nicotina tabacum L. & $\mathrm{P}$ & $\mathrm{P}$ & 0 & 0 & 0 & 09 \\
\hline Callisthene fasciculata Mart. & $\mathrm{P}$ & 0 & $\mathrm{P}$ & 0 & 0 & 08 & Ocimum canum Sims. & $\mathrm{P}$ & $P$ & $\mathrm{P}$ & 0 & 0 & 58 \\
\hline Capsicum frutescens $\mathrm{L}$ & $\mathrm{P}$ & $\mathrm{P}$ & 0 & 0 & 0 & 28 & Orchis sp. & $\mathrm{P}$ & $\mathrm{P}$ & 0 & 0 & 0 & 29 \\
\hline Carica papaya $\mathrm{L}$. & $\mathrm{P}$ & $\mathrm{P}$ & 0 & $\mathrm{P}^{*}$ & 0 & 64 & Passiflora edulis Sims. & $\mathrm{P}$ & $\mathrm{P}$ & 0 & 0 & 0 & 30 \\
\hline Chenopodium ambrosioides L. & $\mathrm{P}$ & 0 & $\mathrm{P}$ & 0 & 0 & 27 & Petiveria alliacea L. & $\mathrm{P}$ & $\mathrm{P}$ & 0 & $\mathrm{P}^{*}$ & $\mathrm{P}^{*}$ & 54 \\
\hline Cinnamomum zeylanicum Blume & $\mathrm{P}$ & $\mathrm{P}$ & 0 & 0 & 0 & 30 & Petroselinum crispum (Mill.) Fuss & $\mathrm{P}$ & $P$ & 0 & 0 & 0 & 22 \\
\hline Cissus sicyoides L. & $\mathrm{P}$ & $\mathrm{P}$ & 0 & 0 & 0 & 12 & Peumus boldus Mol. & $\mathrm{P}$ & $\mathrm{P}$ & 0 & 0 & 0 & 22 \\
\hline Citrus limon L. & $\mathrm{P}$ & $\mathrm{P}$ & 0 & 0 & 0 & 62 & Phyllanthus tenellus Roxb. & $P$ & $\mathrm{P}$ & 0 & 0 & 0 & 32 \\
\hline Citrus sinensis (L.) Osbek & 0 & 0 & $\mathrm{P}$ & $\mathrm{P}^{*}$ & 0 & 36 & Plantago sp. & $\mathrm{P}$ & $\mathrm{P}$ & $\mathrm{P}$ & 0 & 0 & 18 \\
\hline Citrus $\mathrm{x}$ aurantifolia (Christm.) Swingle & $\mathrm{P}$ & $\mathrm{P}$ & 0 & 0 & 0 & 42 & Plectranthus barbatus Andrews & $\mathrm{P}$ & $\mathrm{P}$ & 0 & 0 & 0 & 45 \\
\hline Citrus $x$ aurantium $\mathrm{L}$. & $\mathrm{P}$ & $\mathrm{P}$ & $\mathrm{P}$ & 0 & 0 & 60 & Porophyllum ruderale (Jacq.) Cass. & $\mathrm{P}$ & $\mathrm{P}$ & 0 & 0 & 0 & 26 \\
\hline Costus spiralis (Jacq.) Roscoe & $\mathrm{P}$ & $\mathrm{P}$ & 0 & 0 & 0 & 25 & Psidium guajava L. & $\mathrm{P}$ & $\mathrm{P}$ & 0 & $\mathrm{P}^{*}$ & 0 & 55 \\
\hline Croton salutares Casar. & $\mathrm{P}$ & $\mathrm{P}$ & 0 & 0 & 0 & 26 & Punica granatum L. & $\mathrm{P}$ & $P$ & 0 & 0 & 0 & 30 \\
\hline Cucurbita moschata Dusch & $\mathrm{P}$ & $\mathrm{P}$ & 0 & 0 & 0 & 16 & Rosmarinus officinalis L. & $\mathrm{P}$ & $P$ & 0 & 0 & 0 & 36 \\
\hline Cymbopogon citratus DC. Stapf & $\mathrm{P}$ & $\mathrm{P}$ & 0 & 0 & 0 & 35 & Ruta graveolens $\mathrm{L}$. & $\mathrm{P}$ & $\mathrm{P}$ & 0 & 0 & 0 & 60 \\
\hline Cynara sp. & 0 & $\mathrm{P}$ & $\mathrm{P}$ & 0 & 0 & 17 & Sansevieria trifasciata Prain & $\mathrm{P}$ & $\mathrm{P}$ & 0 & 0 & 0 & 30 \\
\hline Daucus carota L. & 0 & $\mathrm{P}$ & $\mathrm{P}$ & 0 & 0 & 13 & Schinus terebinthifolia Raddi & $\mathrm{P}$ & & 0 & 0 & 0 & 30 \\
\hline Dieffenbachia amoena Bull. & $\mathrm{P}$ & $\mathrm{P}$ & 0 & 0 & 0 & 32 & Senna occidentalis L. & $\mathrm{P}$ & 0 & 0 & $\mathrm{P}^{*}$ & 0 & 51 \\
\hline Echinodorus macrophyllus Kunth & $\mathrm{P}$ & $\mathrm{P}$ & 0 & 0 & 0 & 36 & Solanum melongena $\mathrm{L}$. & $\mathrm{P}$ & $\mathrm{P}$ & $\mathrm{P}$ & 0 & 0 & 20 \\
\hline Eucalyptus globulus Labill. & $\mathrm{P}$ & $\mathrm{P}$ & 0 & 0 & 0 & 20 & Stachytarpheta cayennensis (Rich.) Vahl & $\mathrm{P}$ & $\mathrm{P}$ & 0 & 0 & 0 & 22 \\
\hline Eugenia dysenterica DC. & $\mathrm{P}$ & $P$ & 0 & 0 & 0 & 22 & Strychnos pseudoquina A. St.-Hil. & $\mathrm{P}$ & $P$ & 0 & 0 & 0 & 42 \\
\hline Euphorbia milii Des Moul & $\mathrm{P}$ & $\mathrm{P}$ & 0 & 0 & 0 & 12 & Symphytum officinale L. & $\mathrm{P}$ & $\mathrm{P}$ & 0 & 0 & 0 & 25 \\
\hline Gossypium herbaceum L. & $\mathrm{P}$ & 0 & 0 & 0 & $\mathrm{P}^{*}$ & 60 & Syzygium aromaticum L. & $\mathrm{P}$ & $\mathrm{P}$ & $\mathrm{P}$ & 0 & 0 & 24 \\
\hline Gossypium hirsutum L. & $\mathrm{P}$ & 0 & 0 & $\mathrm{P}^{*}$ & 0 & 44 & Tetradenia riparia (Hochst.) Codd & 0 & $\mathrm{P}$ & $\mathrm{P}$ & 0 & 0 & 10 \\
\hline Hedychium sp. & 0 & $\mathrm{P}$ & $\mathrm{P}$ & 0 & 0 & 04 & Vernonia ferruginea Less. & $P$ & $\mathrm{P}$ & 0 & 0 & 0 & 30 \\
\hline Heteropteris africana A. Juss. & 0 & 0 & 0 & $\mathrm{P}^{*}$ & $\mathrm{P}^{*}$ & 38 & Vernonia polyanthes (Spreng.) Less. & $P$ & $P$ & 0 & 0 & 0 & 18 \\
\hline Holcus mollis L. & $\mathrm{P}$ & 0 & $\mathrm{P}$ & 0 & 0 & 33 & Ximenia americana L. & 0 & 0 & 0 & $\mathrm{P}^{*}$ & $\mathrm{P}^{*}$ & 55 \\
\hline Hydrangea macrophylla (Thunb.) Ser & $\mathrm{P}$ & 0 & $\mathrm{P}$ & 0 & 0 & 22 & Zea mays L. & $P$ & $\mathrm{P}$ & 0 & 0 & 0 & 38 \\
\hline Ipomoea batatas (L.) Lam. & $\mathrm{P}$ & $\mathrm{P}$ & 0 & 0 & 0 & 22 & Zingiber officiallis Roscoe & 0 & $\mathrm{P}$ & 0 & $\mathrm{P}^{*}$ & 0 & 62 \\
\hline
\end{tabular}

*Vouchers: For plants collected in Santa Catarina voucher numbers are FLOR 60878 to 60886, 60894 to 60897 and EAFM 12991 to 13458. For plants collected in Mato Grosso voucher numbers are UFMT 41495 to 41712 and 42344 to 42408 . For plants collected in Portugal voucher numbers are LISC 48975 to 49059. For Guine Bissau and Mozambique the plants marked with an * were identified based on literature (Catarino 2002; Gomes et al. 2006; Ribeiro et al. 2010). 
officinalis, Mentha pulegium and Leonotis nepetifolia, which are present in the communities of Santa Catarina and Mato Grosso (first group). Comprising a second group, Mentha $\mathrm{x}$ villosa and Ocimum canum are present in the communities of Santa Catarina, Mato Grosso and Penha Garcia. Tetradenia riparia stood apart from the other species of Lamiaceae and is present in the communities of Santa Catarina and Penha Garcia (Fig. 2).

Table 2. Number of citations of uses of medicinal plants in Afrodescendant communities: Brazil, Europe and Africa. Categories: $\mathrm{M}=$ Medical; $\mathrm{Al}=$ Food, and $\mathrm{Pr}=$ Protection (mystic-religious) .

\begin{tabular}{|c|c|c|c|c|}
\hline Categories & Brazil & Europe & Africa & Total \\
\hline $\mathrm{M}$ & 1,182 & 381 & 728 & 2,291 \\
\hline $\mathrm{M}, \mathrm{Al}$ & 701 & 198 & 322 & 1,221 \\
\hline $\mathrm{M}, \mathrm{Pr}$ & 581 & 183 & 306 & 1,070 \\
\hline Number of Interviews & 226 & 40 & 71 & 337 \\
\hline
\end{tabular}

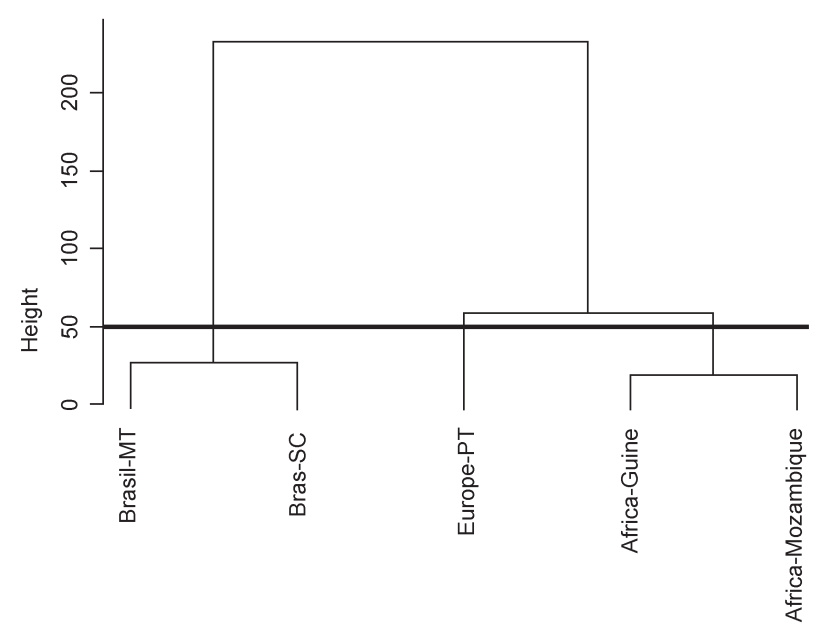

Agglomerative Coefficient $=0.87$

Figure 1. Cluster of similarity in the communities of Brazil - Mato Grosso (Brasil-MT); Brazil - Santa Catarina (Brazil-SC); Africa - Guinea Bissau; Africa - Mozambique; Europe - (Portugal-PT).

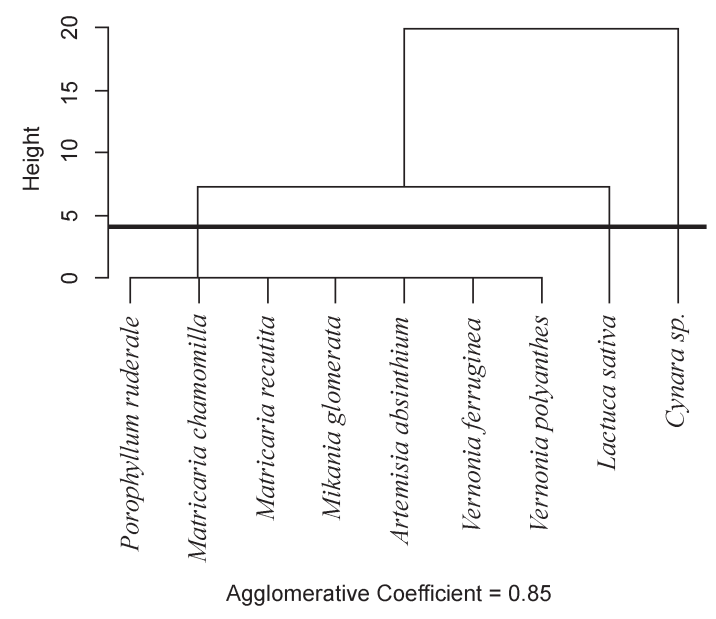

Figure 2. Agglomerative distribution of species of the family Lamiaceae.
The coefficient of agglomeration for Asteraceae was 0.88, with nine species with similar uses. Porophyllum ruderale, Matricaria chamomilla, Matricaria recutita, Mikania glomerata, Artemisia absinthium, Vernonia ferruginea and Vernonia polyanthes are clustered in the first group, with all species being present in the Brazilian communities. Lactuca sativa and Cynara sp. are present in the communities of Brazil and Portugal and formed the second group (Fig. 3).

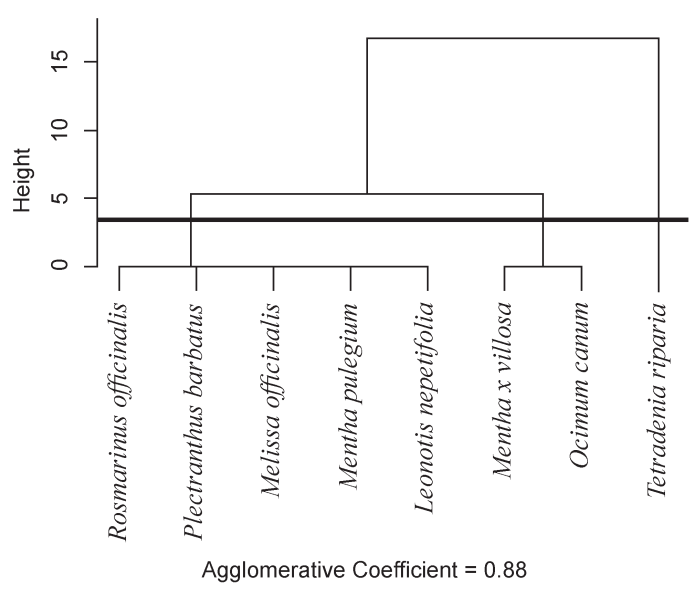

Figure 3. Cluster of agglomeration of the family Asteraceae.

\section{Discussion}

The general characteristics of ethnobotanical knowledge of medicinal plants found in the present study are similar to those reported by other studies. Voeks (2007) and Conde et al. (2017) found similar results regarding the predominance of older people among the interviewed experts on medicinal plants. The importance of the knowledge held by women about medicinal plants among Afro-descendant communities reflects the social distribution of labor of these communities, as was also observed by Voeks (2007). This knowledge of nature among women is usually related to anthropogenic landscapes, such as gardens and backyards. Located close to homes, these spaces are accessible and shelter plants from the activities of more intensively managed areas where planting, sweeping and cleaning occur (Amorozo 2013). Pasa et al. (2017) found that men who work in forests and less managed habitats have more knowledge about medicinal forest species, while women are more proficient in medicinal herbs. Women and men clearly possess different knowledge of their local floras, which is especially pronounced for tropical healing floras (Voeks 2007).

The predominance of the Catholic religion reflects the historical characteristics of each country. In addition, there is historical convergence between West African and Catholic belief systems into syncretic religions, which was already under way even prior to the Atlantic crossing. This convergence intensified among slaves in Brazil and became part of the earliest Quilombo societies, as pointed out by Anderson (1996) and Santos (2013). 
The studied communities are located on different continents and in different biomes, and interact with a variety of plants when practicing traditional medicine. Although the results presented here show a tenuous similarity in the species used, there are some shared species in the traditional knowledge about medicinal plants of the communities, which may represent a legacy in Afrodescendant communities, uniting them through a cultural bias over time and space. However, shared species can also be influenced by shared historical drivers related to Portuguese expansion, which contributed to the homogenization of the floras used among different continents (Crosby 1993).

The greatest similarity was among the Brazilian communities, followed by the African communities. Similarity in the Brazilian (especially for Mato Grosso) and African communities may have been influenced by their geographic location because both are in tropical regions and thus share a tropical environment: Neotropical for Mato Grosso, and Afro-tropical for Guinea Bissau and Mozambique. In other words, there are similar ecosystems on continents with different biogeographic histories, which favors a similar set of introduced plants. The most different set of medicinal plants was that of Portugal (Fig. 1).

Asteraceae is one of the largest families of Angiosperms and is widely distributed around the world. It is very well represented in Brazil, especially in open environments, such as cerrado (Hattori \& Nakajima 2008; Souza et al. 2018). Lamiaceae is present in all Brazilian biomes (Lewis et al. 2005; Souza et al. 2018). Both of these families include several introduced species originally from the Mediterranean region. In the Portuguese community of Penha Garcia, species of Lamiaceae are found in environments known as guirras (open forests) (Costa 1998), which shelter aromatic plants, among which the most cited were Rosmarinus officinalis, Ocimum sp., Mentha x villosa and Mentha pulegium. Both of these botanical families possess extraordinary medicinal potential and are used extensively in Afro-descendant gastronomy due to the trajectory of occupation between the Old and New Worlds.

The flow of plants from tropical Africa to the Americas occurred over many years, whether intentionally or not. As part of this botanical trajectory came a domesticated flora from distant regions (Voeks 2017). Crosby (1993) called this process the "Colombian exchange", because it contributed to botanical homogenization of the world. It also favored African readjustment and transculturation through the diffusion of food and magico-religious plants among descendants in the New World, who could thereby claim a degree of sovereignty against European and American hegemony (Voeks \& Rahsford 2013). Anacardium occidentale, Musa parasidiaca, Jatropha gossypiifolia, Senna occidentalis, Gossypium hirsutum, Citrus sinensis and Zingiber officiallis were all recorded for the African communities, yet also found in the repertoires of the communities in the Americas and in Portugal, evidencing a mixture of plants from different origins.
According to Voeks \& Greene (2018) "the colonial era witnessed a feverish search for exotic medicinal plants by European physicians and scientists". These authors also considered indigenous and diasporic peoples as "warehouses of plant knowledge". The conquest and colonization of the Americas also heralded inadvertent and intentional biological exchanges of unprecedented proportions, which accelerated the pace of biogeographical processes of exchange between the Old and New Worlds. According to Parsons (1970), "the introduction of African grasses in the Americas (...) represented one of the most significant ecological invasions in Earth's history". Pre-Colombian New World communities relied on staple foods consisting of corn, manioc, pumpkin, beans, peanuts, and sweet potatoes. People from the Old World adopted native American fruits in their diet, such as passion fruit, guava, cashew, and papaya, among others. The Amerindian food base was expanded and mixed with products of plants brought from the Old World, such as wheat, white rice, vegetables and bananas, to name a few, which were naturalized and incorporated into the diet of the population (Voeks 2016). In manipulating environmental resources for survival and resistance, Africans resorted to creating diverse ethnobotanical traditions that underpinned the rural black cultures of the Americas. According to Voeks (2017), African knowledge applied to the Neotropical landscape "provided cultural and environmental readaptation in the New World, new relationships with wild and domesticated nature, and genetic exchange of plants between continents".

According to Löwenberg-Neto (2010), who analyzed aspects of biogeography, the high variety and low similarity of plant species could have been influenced by endemism in the different biomes (Cerrado, Atlantic Forest, Mediterranean Forests and African Forests). For example, several species present in the European community of Penha Garcia are native to the temperate area there in the Mediterranean domain. Of the 25,000 species of flowering plants identified in this region, which is about $10 \%$ of all known plants in the world, more than half are endemic to the region (Franco 1984; Crosby 1993; Costa 1998). Consequently, several characteristic species of this biome are not found in the other communities in Africa or South America (Franco 1996; Aguiar et al. 1997; Barrio \& Teixido 2015).

The diversity of plants used in traditional medicine in the studied Afro-descendant communities reflects the floristic richness of the local biomes and is directly related to availability in natural habitats, yet also reflects exchanges that occurred since the diaspora. Several introduced plants are grown in anthropically modified spaces, such as backyards and gardens. Voeks (2017) describes gardens and backyards as man-made spaces that can be considered cultural or domesticated landscapes. In Afro-descendant communities these spaces usually possess a mixture of both native and exotic species (Ávila et al. 2015). 
The number of species and genera recorded in the traditional medicine of the studied localities significantly bolsters the diversity represented by botanical families, with Lamiaceae having the greatest number of species, followed by Asteraceae, Myrtaceae and Rutaceae. For Conde et al. (2017), the diversity expressed by traditional knowledge may be due to the fact that the ethnobotanical knowledge of Quilombo residents includes a combination of African, Amerindian and European knowledge of plants. Furthermore, this author reveals that Dalbergia hortensis is the species with the highest cultural significance index (CSI) in Quilombo communities of Minas Gerais. This record can be considered to ethnobotanically approximate, at the generic level, Dalbergia melanoxylon, which had 42 citations of medicinal uses in the Afro-descendant community in Mozambique.

Some plants have multiple uses, being classified as medicinal along with other categories of use, such as food. For example, in the Portuguese community of Penha Garcia, Geranium purpureum is used as a medicine to treat liver disease, colitis and belly pain, as well as a food in the form of bread soup (Esteves \& Silva 2015). In Brazilian Quilombo communities, medicinal plants are used to treat health problems, such as hypertension, sickle-cell anemia and diabetes mellitus, that are of particular significance as diseases of ethnic origin in Afro-descendant populations (Brasil 2001; Pasa et al. 2015; Zank et al. 2016). In the Quilombo community of Boqueirão, Alto Guaporé, in Mato Grosso, the fruit of açaí (Euterpe sp.) is used as medicine in the form of juice and wine for the treatment of anemias, while the leaf is prepared as tea (Leite \& Silva 2014).

According to Krog et al. (2006), the plant part used and the frequency of use may represent a threat to plant populations. Species such as Voacanga africana and Warburgia salutaris, with proven antibacterial properties, are a source of concern for local researchers who are aware of their use in traditional treatments for malaria, fever, cough and abdominal pain in African communities. Slow-growing species with limited distributions become vulnerable to overexploitation, which may compromise African biodiversity (Izidine \& Bandeira 2002). Researchers are calling for the development of sustainable management plans that consider local knowledge and management of plant use. According to Conde et al. (2017), the development of programs, including agroforestry programs, aimed to increase population sizes of these endangered species can help meet the cultural needs of of Afro-descendant communities. Many plants are used in religious rituals, prayers or blessings for personal protection (mystic-religious), almost always by elderly people with experience with plants. This knowledge is culturally transmitted between generations. The leaves, stems and flowers of Rosmarinus officinalis and Ruta graveolens are used in personal protection rituals to treat the evils of body and soul. According to deponents, these plants have power against "evil eye" and are used in baths for corporal and spiritual cleansing. the extensive use of such plants by Quilombolo residents is likely related to their African cultural heritage (Ávila et al. 2015; Pasa \& David 2016; Fonseca \& Balick 2018). The use of plants in religious or symbolic rituals reveals the extent of the importance of medicinal plants, as has been observed by other authors (Zank \& Hanazaki 2017; Fonseca \& Balick 2018). In addition to the direct use of medicinal plants, traditional medicine serves as a resource for cultural affirmation in in the face of the dominant medical system, and so its maintenance helps to maintain traditional means of subsistence and to conserve local ecosystems (Zank \& Hanazaki 2017).

The broad ethnobotanical corpus developed in Africa over millennia also includes plants used as stimulants for rituals and magic. Contemporary Afro-Brazilians, for instance, recognize that elements of their local ethnoflora also inhabit their ancestral West African homeland. According to Pfeiffer \& Voeks (2008) and Voeks (1997), plants used in "Candomblé" (religious practice related to African ancestry), are called "West African Coast Leaf" and mint (Aframomum melegueta), and represent the African legacy of Afro-Brazilian culture.

For Fonseca \& Balick (2018), an inventory of liturgical plants used by Candomblé practitioners in Brazil and by the diaspora living in New York City reveals some consensus with our study. Species included, such as Abelmoschus esculentus, Artemisia sp., Allium sp., Aloe vera, Annona acutiflora, Artemisia absinthium, Capsicum sp., Chenopodium ambrosioides, Cinnamomum sp., Citrus $x$ aurantium, Dieffenbachia amoena, Eugenia sp., Gossypium hirsutum, Jatropha gossypiifolia, were also present in the Afro-descendant communities studied here.

\section{Conclusions}

We conclude that traditional knowledge of plants used as remedies in Afro-descendant communities is expressed in the daily life of people and represents a cultural and environmental heritage passed down through generations. The practice of traditional medicine in the studied communities is the most immediate and economical way they have of treating health problems, since most of these communities are far from urban centers. The plant resources used in traditional Afro-descendant medicine come from a great variety of plants, which favors the therapeutic needs of the communities. Similarities among the studied communities with regard to the presence or absence of plants are tenuous. This is probably due different sets of medicinal plants resulting from biogeographical and spatial characteristics of the respective biomes and the historical and cultural peculiarities of each locality. This study contributes to a better understanding of the historical legacies of the African diaspora and of European (Portuguese) expansion as agents in the modeling of Neotropical environments, the introduction of European plants in Africa, and the adaptation and maintenance of new elements in local floras. 


\section{Maria Corette Pasa, Natalia Hanazaki, Olga Maria Duarte Silva, Adelaide Bela Agostinho, Sofia Zank and Maria Inês Pires Neves Esteves}

Considering the size of the studied areas; their distance, access and availability for data collection; and that the studies occurred at different times with different objectives and procedures, there are certainly interpretative limitations to our results. However, our intent was to perform a preliminary study comparing the use of medicinal plants by Afro-descendant groups on different continents. This study does not provide an exhaustive ethnobotanical documentation of the studied areas. Such an effort is still needed, and would pave the way for future phytochemical studies. Therefore, we recommend that future research address the taxonomic and phylogenetic proximity of species comprising the medicinal flora used by Afro-descendants on different continents. Finally, documenting and disseminating information on the use of medicinal plants in Afro-descendant communities, where ethnomedicinal practices are still traditional and follow cultural pluralities, will help to strengthen local values and the richness of different cultures and traditions.

\section{References}

Agostinho AB. 2002. Traditional medicine in Mozambique: overview and perspectives. 2001-2010 OAU Decade for African Traditional Medicine 5: 118-120.

Aguiar C, Penas A, Lousã M. 1997. Vegetación endémica, no rupicola, de las rocas ultrabásicas de "Trás-os-Montes". Anais da Sociedade Brotéria 60: 1-11.

Albuquerque UP, Hanazaki N. 2006. As pesquisas etnodirigidas na descoberta de novos fármacos de interesse médico e farmacêutico: fragilidades e perspectivas. Revista Brasileira de Farmacognosia 16: 678-689.

Amorozo MCM. 2004. Pluralistic medical setting and medicinal plants use in rural communities, Mato Grosso, Brazil. Journal of Ethnobiology 24: 139-161.

Amorozo MCM. 2013. Sistemas agrícolas de pequena escala e a manutenção da agrobiodiversidade - uma revisão e contribuições. Rio Claro/ Botucatu, Edição do autor/ FCA - UNESP.

Anderson RN. 1996. The Quilombo of Palmares: a new overview of a maroon state in seventeenth-century Brazil. Journal of Latin American Studies 28: 545-566.

APG IV - Angiosperm Phylogeny Group. 2016. An update of the Angiosperm Phylogeny Group classification for the orders and families of flowering plants: APG IV. Botanical Journal of the Linnean Society 181: 1-20.

Ávila JVC, Zank S, Valadares KMO, Maragno JM, Hanazaki N. 2015. The Traditional knowledge of quilombola about plants: does urbanization matter? Ethnobotany Research \& Applications 14: 453-462.

Barrio M, Teixido AL. 2015. Perspectives in Plant Ecology. Plant Systematics and Evolution 301: 113-124.

Brasil. 2001. Manual de doenças mais importantes, por razões étnicas, na população brasileira afrodescendente. Brasília, Ministério da Saúde, Secretaria de Políticas de Saúde.

Catarino FML. 2002. Flora e Vegetação do Parque Natural das Lagoas de Cufada, Guiné-Bissau. Lisboa, Instituto de Investigação Cientifica Tropical - Centro de Botânica.

Conde BE, Ticktin T, Fonseca AS, et al. 2017. Local ecological knowledge and its relationship with biodiversity conservation among two Quilombola groups living in the Atlantic Rainforest, Brazil. PLOS ONE 12:e0187599. doi: 10.1371/ journal.pone.0187599

Costa J. 1998. Biogeografia de Portugal Continental. Lisboa, Quercetea.

Crosby AW. 1993. Ecological imperialism: the biological expansion of Europe, 900-1900. Cambridge, Cambridge University Press.
Diniz MA, Martins ES, Gomes E, Silva O. 2000. Contribution for the knowledge of medicinal plants from Guinea-Bissau. Portugaliae Acta Biologica 19: 417-427.

Esteves MIP, Silva OMd. 2015 Uso de plantas medicinais em Penha Garcia. Lisboa, FFULisboa.

Faria T. 2010. Etnobotânica da aldeia de Canhane: plantas úteis, saberes locais e tradições. Maputo, Diname Pub.

Fonseca FN, Balick MJ. 2018. Plant-knowledge adaptation in an urban setting: candomblé ethnobotany in New York City. Economic Botany 72: 56-70.

Franco JA. 1984. Nova Flora de Portugal. Lisboa, Escolar Editora.

Franco JA. 1996. Zonas fitogeográficas predominantes em Portugal Continental. Anais do Instituto Superior de Agronomia 44: 39-56.

Gomes ET, Silva O, Diniz MA, Martins ES. 2006. Plantas medicinais de Guiné Bissau: manual prático. Acção para o Desenvolvimento (AD), Guiné-Bissau. Lisboa, Faculdade de Farmácia de Lisboa.

Gomes PJ, Barbosa LAG. 1995. Esboço do reconhecimento ecológico-agrícola de Moçambique. Lourenço Marques. Centro de Investigação Científica Algodoeira: Memórias e Trabalhos 23: 67-226.

Hair JR, William B, Babin B. 2009. Análise multivariada de dados. 6th. edn. Porto Alegre, Bookman.

Hattori EKO, Nakajima JN. 2008. A família Asteraceae na Estação de Pesquisa e Desenvolvimento Ambiental Galheiro, Perdizes, Minas Gerais, Brasil. Rodriguésia 59: 687-749.

IBGE - Instituto Brasileiro de Geografia e Estatística. 2010. Censo 2010. https://ww2.ibg e.gov.br/home/geociencias/geografia/ mapas_doc5.shtm. Aug. 2017.

Izidine S, Bandeira SO. 2002. Mozambique. In: Golding JS. (ed.) Southern African plant red data lists. Southern African Botanical Diversity Network Report Series. Pretoria, National Botanical Institute. p. 43-53.

Johnson RA, Wichern DW. 2007. Applied multivariate statisitical analysis. 6th. edn. Upper Saddle River, Pearson/Prentice Hall.

Krog MP, Falcão MP, Olsen CS. 2006. Medicinal plant markets and trade in Maputo, Mozambique. Hørsholm, Christian Ejlers.

Leite JC, Silva VC. 2014. Quilombolas do Vale do Guaporé: modos de conhecimento e territorialidade. Cuiabá, Edufmt/Ed. Sustentável.

Lewis GP, Schrire B, Mackinder B, Lock M. 2005. Legumes of the World. Kew, Royal Botanic Gardens.

Lorenzi H. 2013. Plantas para jardim no Brasil: herbáceas, arbustivas e trepadeiras. Nova Odessa, Plantarum.

Lorenzi H, Matos FJA. 2008. Plantas medicinais no Brasil: nativas e exóticas. 2nd. edn. Nova Odessa, Plantarum.

Löwenberg-Neto P. 2010. Conservação da biodiversidade e biogeografia histórica. In: Carvalho CJB, Almeida EAB. (orgs.) Biogeografia da América do Sul: padrões e processos. São Paulo, Roca. p. 186-196.

M’Bokolo EM. 2007. África Negra: História e Civilizações do século XIX aos nossos dias. Lisboa, Edições Colibri.

Martins MAGD. 1996. Flora e vegetação da Guiné-Bissau. Programa de Investigação. Lisboa, IMed.

Meihy JCSB. 1996. Manual de história oral. São Paulo, Loyola.

Minayo MCS. 1994. O desafio da pesquisa social. In: Minayo MCS. (org.) Pesquisa social: teoria, método e criatividade. 29th. edn. Petrópolis, Vozes.

Minayo MCS. 2007. O desafio do conhecimento: pesquisa qualitativa em saúde. 10th. edn. São Paulo, Hucitec.

Munanga K. 2004. Uma abordagem conceitual das noções de raça, racismo, identidade e etnia. Cadernos Penesb 5: 15-34.

Parsons JJ. 1970: The 'Africanization' of the New World tropical grasslands. Tubingen Geographische Studien 34: 141-53.

Pasa MC, David M. 2016. Chestnut-of-Brazil (Bertholletia excelsa Bonpl.) - Lecythidaceae: Ethnobotany in Forests of Brazil. Amazonian. Flovet 1: 77-88.

Pasa MC, David M, Dorval A, et al. 2015. Múltiplos olhares sobre a biodiversidade. In: Pasa MC. (org.) A etnobiologia na baixada cuiabana. São Paulo, Carlini \& Caniato Editorial. p. 341- 368. 


\section{Medicinal plants in cultures of afro-descendant communities \\ in Brazil, Europe and Africa}

Pasa MC, Zurra RMO, David M. 2017. Múltiplos olhares sobre a biodiversidade. In: Pasa MC, David M. (orgs.) Caminhando com os ribeirinhos pela Amazônia Brasileira. São Paulo, Carlini \& Caniato Editorial. p. 537-548.

Pfeiffer JM, Voeks RA. 2008. Biological invasions and biocultural diversity: linking ecological and cultural systems. Environmental Conservation 35: 281-293.

Ribeiro AI, Romeiras MM, Tavares J, Faria MT. et al. 2010. Ethnobotanical survey in Canhane village, district of Massingir, Mozambique: medicinal plants and traditional knowledge. Journal of Ethnobiology and Ethnomedicine 3: 6-33.

Salas A, Richards M, Lareu MV, et al. 2004. The African Diaspora: Mitochondrial DNA and the Atlantic Slave Trade. American Journal of Human Genetics 74: 454-465.

Santos MW. 2013. Festas quilombolas: Entre a tradição e o sagrado, matizes da ancestralidade africana. Revista HISTEDBR 50: 286-300.

Silva VA, Andrade LHC, Albuquerque UP. 2006. Revisiting the Cultural Significance Index: the case of the Fulni-oÃ in Northeastern Brazil. Field Methods 18: 98-108.

Silva OMD, Viegas S, Mello-Sampayo C, et al. 2012. Anti-Helicobacter pylori activity of Terminalia macroptera root. Fitoterapia 83: 872-878.

Souza VC, Flores TB, Colletta GD, et al. 2018. Guia das Plantas do Cerrado. Piracicaba, Taxon Brasil.

Tongco MDC. 2007. Purposive Sampling as a Tool for Informant Selection. Ethnobotany Research and Applications 5: 147-158.

Voeks RA 1997. Sacred Leaves of Candomblé: African Magic, Medicine, and Religion in Brazil. Austin, University of Texas Press.
Voeks RA 2007. Are women reservoirs of traditional plant knowledge? Gender, ethnobotany and globalization in northeast Brazil. Singapore Journal of Tropical Geography 28: 7-20.

Voeks RA. 2016. Introduction to Ethnobiology. In: Albuquerque UP, Alves RRN. (ed). Diaspora ethnobiology. São Paulo, Springer. p. 39-45.

Voeks RA. 2017. Ethnobotany. In: Internacional Encyclopedia of Geography. Fullerton, John Wiley \& Sons 1: 1- 4.

Voeks RA, Rashford J. 2013. African ethnobotany in the Americas. New York, Springer.

Voeks RA, Greene C. 2018. God's healing leaves: The colonial quest for medicinal plants in the Torrid Zone. Geographical Review 108: 545565.

WHO 2002. Wold Health Organization. reducing risks, promoting healthy life. Geneva, World Health Organization. http://www.who. int/whr/2002/en/whr02_en.pdf. 4 Jun. 2017.

WHO 2007.Classificação estatística internacional de doenças problemas relacionados à saúde. 10th edn. São Paulo, Editora da Universidade de São Paulo.

WHO 2014. International statistical classification of diseases and related health problems. Geneva, World Health Organization. http://apps. who.int/classifications/icd10/browse/2014/. 24 Feb. 2017.

Zank S, Ávila JVC, Hanazaki N. 2016. Compreendendo a relação entre saúde do ambiente e saúde humana em comunidades Quilombolas de Santa Catarina. Revista Brasileira de Plantas Medicinais 18: 157-167.

Zank S, Hanazaki N. 2017. The coexistence of traditional medicine and biomedicine: A study with local health experts in two Brazilian regions. PLOS ONE 12: 0174731. doi: 10.1371/journal.pone.0174731 